\title{
Facilitators and Obstacles in Youth Saving: Perspectives from Ghana and Kenya
}

\author{
Li Zou $^{1} \cdot$ Sarah Myers Tlapek ${ }^{1} \cdot$ Githinji Njenga $^{2} \cdot$ Ernest Appiah $^{3}$. \\ Dorcas Opai-Tetteh $^{3} \cdot$ Margaret S. Sherraden $^{4}$
}

Published online: 28 April 2015

(C) Springer International Publishing 2015

\begin{abstract}
Youth are a rapidly growing percentage of the SubSaharan African population, and many are economically vulnerable. Financial inclusion for youth, particularly the promotion of savings behavior, is associated with a number of positive social and economic outcomes and is an international priority. However, the majority of youth in Sub-Saharan Africa are not saving, and limited qualitative research exists to aid understanding of the possible explanations. This paper aims to increase the understanding of factors that facilitate and obstruct youth saving by exploring the savings behavior of youth participating in the YouthSave Project in Ghana and Kenya. We conducted in-depth interviews with four triads comprised of youth, a parent or caregiver, and a school stakeholder in each country to develop case studies for the YouthSave Project. Findings indicate that support from parents, school staff, and financial institutions is conducive to youth participation in saving, even though youth participants struggle with limited financial resources and conflicting demands for money. Understanding the reasons, both institutional and individual, that youth in Ghana, Kenya, and other Sub-Saharan countries are not saving is an important part of promoting financial inclusion and greater use of banking services. This study provides first-hand accounts that may be useful for financial institutions, policymakers, and others working to develop youthfriendly financial products and establish financial inclusion policies.
\end{abstract}

Li Zou

lzou@wustl.edu

Washington University in St. Louis, St. Louis, MO, USA

2 Kenya Institute for Public Policy Research and Analysis, Nairobi, Kenya

3 University of Ghana, Accra, Ghana

4 University of Missouri - St. Louis, St. Louis, MO, USA
Keywords Youth saving $\cdot$ Facilitators $\cdot$ Obstacles $\cdot$ Financial inclusion $\cdot$ YouthSave $\cdot$ Ghana $\cdot$ Kenya

\section{Introduction}

Youth in Sub-Saharan Africa represent a rapidly growing percentage of the region's population. More than one third of the population in Sub-Saharan Africa is aged between 10 and 24 years. By 2050, UNICEF estimates that $37 \%$ of the world's population aged younger than 18 years will live in Africa, and two thirds of those will be in West or East Africa (Hervish and Clifton 2012; UNICEF 2014). In spite of advances in health and education in many African countries, Sub-Saharan youth face multiple challenges to social and economic development and well-being. Nearly half of the population in Sub-Saharan Africa lives below the international poverty level established by UNICEF (US\$ 1.25 per day), and the African continent has the highest concentration of death among children and youth aged younger than 18 years of any region in the world (UNICEF 2014). On a global level, youth are more than three times more likely than adults to be unemployed. Negative trends in labor and employment affect youth more than adults; they may have more trouble finding work in a tight labor market because of their limited skills and experience (International Labour Organisation 2012).

Although Ghana and Kenya have made dramatic improvements in youth well-being in some areas such as education and civic participation, youth in these countries continue to face substantial hurdles (Center for Strategic and International Studies [CSIS] and International Youth Foundation [IYF] 2014; Hervish and Clifton 2012). Kenya, where $33 \%$ of the population is aged between 10 and 24 years, has one of the highest rates of school attendance; for youth of lowersecondary-school age, less than $1 \%$ of boys and less than $2 \%$ of girls do not attend school (Hervish and Clifton 2012). However, many Kenyan youth are engaging in risky 
sexual behaviors, and adolescent fertility is high, with 98 out of 1000 births from adolescent girls (Hervish and Clifton 2012). Economic opportunities are limited for many Kenyan youth (CSIS and IYF 2014). More than $90 \%$ of children in Ghana advance from primary to secondary school, but retention in secondary school remains a problem. Among students of secondary-school age, $46 \%$ of males and $60 \%$ of females are out of school. Child labor and adolescent fertility are also high in Ghana; $6 \%$ of females aged between 15 and 19 years give birth each year, and $34 \%$ of children aged five to 14 years engage in economic activity or household chores (Hervish and Clifton 2012).

The World Bank and others have identified financial inclusion as an international priority. Defined as access to highquality and affordable financial services, financial inclusion is important for economic and social development and poverty reduction (Children and Youth Finance International 2012; World Bank 2014). A rapidly growing body of evidence demonstrates that financial inclusion for youth, particularly involvement in savings programs, is associated with a wide range of positive outcomes in areas such as health, education, social-emotional development, and financial well-being (Chowa et al. 2013; Huang et al. 2014; Ssewamala et al. 2009). Having savings has been associated with greater income and assets, better reproductive and preventive health knowledge, improved physical and mental health, academic achievement, and performance in a number of studies in SubSaharan Africa (Child and Youth Finance International Research Working Group 2012; Sharma et al. 2015).

Financial institutions around the world are providing financial products for youth; a recent desk review of 135 banks in 69 countries found that $84 \%$ of institutions in the sample provided youth or child accounts, including $87 \%$ of the 23 banks assessed in Africa (Child and Youth Finance International Research Working Group 2013). However, these products may not be truly "child- and youth-friendly," and are likely a small portion of the institution's overall operations (Children and Youth Finance International Research Working Group 2013; Kilara et al. 2014).

In fact, available data indicate that the majority of youth in Sub-Saharan Africa are not saving or using banking services. The World Bank estimates that $9.32 \%$ of young adults (aged 15-24 years) in Sub-Saharan Africa saved in a formal financial institution in the past year (Demirguc-Kunt and Klapper 2012). Fourteen percent of young adults had saved in the past year in a savings club (Demirguc-Kunt and Klapper 2012). Recent national surveys of youth in Ghana and Kenya found that reported access to banking and actual use of banking services were often substantially different. In Kenya, $51 \%$ of youth (aged 15-19 years) reported no access to any banking services, and $84 \%$ reported no use of banking services in the past year (Montez 2010). In Ghana, $28 \%$ of youth (aged 15 24 years) reported no banking access, and $68 \%$ had not used any services in the past year. Results were worse for rural youth in Ghana; $78 \%$ reported no use of banking services (Montez 2010).

Understanding the reasons, both institutional and individual, that youth in Ghana, Kenya, and other Sub-Saharan countries have low rates of saving is an important part of promoting financial inclusion and greater use of banking services. Theories of saving and asset accumulation often focus on individual constructs such as knowledge, economic resources, and family support; however, an institutional conceptual framework acknowledges the additional role of policies, programs, and the products and services provided by financial institutions (Beverly et al. 2008). Institutional features such as access, incentives, restrictions, and security may all influence savings behavior; individuals save when structured mechanisms conducive to saving are in place (Beverly et al. 2008).

This paper provides qualitative evidence from youth, their parents or caregivers, and school stakeholders (i.e., teachers, principals, school staff, administrators) on their saving experiences in the YouthSave initiative. Youth perspectives can guide policy and service. Prior qualitative studies with youth, parents or caregivers, and school stakeholders have shown to be extremely valuable in identifying individual and institutional factors related to savings behavior (Murphy-Erby et al. 2014; Scanlon and Adams 2008; Scanlon et al. 2009; Sherraden et al. 2013; Ssewamala et al. 2012; WheelerBrooks and Scanlon 2009; Zou and Sherraden 2009). However, only a limited number of qualitative studies have examined the perspectives of youth in Sub-Saharan Africa toward savings and participation in savings programs (for an exception, see Ismayilova et al. 2012).

This paper aims to contribute to the limited research from Sub-Saharan Africa by presenting case studies of youth participants in the YouthSave program in Ghana and Kenya. The study examines the perspectives of four triads comprised of youth from the two countries, their parents or caregivers, and school stakeholders. The study addresses the following questions: (1) What do the selected youth consider to facilitate savings and encourage participation in a savings program? and (2) What do these youth consider as obstacles or hindrances to savings behavior and participation in savings programs?

\section{The YouthSave Project}

In partnership with MasterCard Foundation, YouthSave is a 5-year (2010-2015) project that aims to investigate the potential of savings accounts as a tool for youth development and financial inclusion in four developing countries - Colombia, Ghana, Kenya, and Nepal. A global consortium includes four US-based organizations: Save the Children (SC) Canada and USA, the Center for Social Development (CSD) at 
Washington University in St. Louis, the Consultative Group to Assist the Poor (CGAP), and the New America Foundation. The global consortium works closely with local financial and research partners in the four YouthSave countries. ${ }^{1}$

In Ghana, the YouthSave Project's financial partner is HFC Bank and its research partner is the Institute of Statistical, Social and Economic Research (ISSER) at the University of Ghana. HFC Bank is a full-fledged bank that offers a full range of retail banking and investment products; the bank's joint venture with Boafo Microfinance Services provides additional delivery channels for low-income customers. HFC launched the YouthSave product called Enidaso (which means "hope") in May 2012 after conducting extensive market research (Deshpande 2012). Enidaso requires youth to keep a minimum balance of GHS 2 (US\$ 0.60) and provides $1.25 \%$ interest. The research partner ISSER is the leading research institution in social and economic development in Ghana and West Africa; ISSER's areas of research focus include economic growth, household consumption behavior and patterns, poverty, and livelihoods.

In Kenya, YouthSave's financial partner is the Kenya Post Office Savings Bank (Postbank) and its research partner is the Kenya Institute for Public Policy Research and Analysis (KIPPRA). Postbank is the second largest financial institution in Kenya that reaches the country's poor population. Prior to YouthSave, Postbank had success with a group-based youth account. Postbank launched the SMATA account (which means "being smart") in July 2012 with a youth-friendly minimum balance requirement of KSH 50 (US\$ 0.55). The research partner KIPPRA is an autonomous public institute among the top think tanks in Kenya with a mission to provide public-policy advice to Kenya's government and its private sector.

The Washington University in St. Louis Institutional Review Board, the Kenyan National Council for Science and Technology, and the Institutional Review Board of the University of Ghana approved the research portion of the YouthSave Project.

\section{Methods}

\section{In-depth Interviews with Youth, Parents or Caregivers, and School Stakeholders}

To address the research questions, this study used a multiple case-study approach across two countries that included indepth interviews with youth participants, parents or caregivers, and school stakeholders. The research team chose an in-depth exploratory, qualitative case-study approach to explore savings behavior and the way saving takes place in each

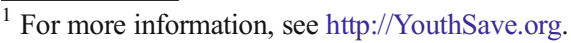

specific family, community, and country context (Creswell 2013).

\section{Interview Guide}

The interviews with youth explored the following topics: experiences with the YouthSave account, family history of savings, prior saving, plans for YouthSave account savings, challenges and facilitators to saving, and perceived impact of saving to date.

Interviews with parents or caregivers explored their financial education and experience with saving, their child's financial education at home, their own experience with YouthSave, and their perception of savings impact to date. Interviews with school stakeholders included topics such as the financial education the community or school provided to youth, the story of YouthSave in the community, and the school stakeholders' perception of impact. The research team developed three indepth interview guides for youth, their parents or caregivers, and school stakeholders in two steps: (1) building on the indepth interview guide developed for CSD's American Dream Demonstration and the I Can Save projects and (2) modifying the guide for YouthSave in the Ghanaian and Kenyan contexts (Center for Social Development 2011; Sherraden et al. 2005). Research partners in both countries contributed to the development of the interview guide and pilot-tested it prior to its implementation. After pilot-testing, research partners translated the interview guide into the language most comfortable for participants in each country.

\section{Sampling and Informed Consent}

The research partners developed case studies from interviews with four triads consisting of a youth participant, one of his or her parents or a caregiver, and a stakeholder from the youth's school. In total, 12 respondents completed in-depth interviews to make up the case studies. Research partners worked in coordination with the YouthSave financial institution in each country to select youth who were considered to have had enough experience with the account (i.e., youth who had opened the savings account 5 months to more than a year prior) for inclusion as a participant in the interview. To select youth, research partners examined data on savings balances, length of account operation, deposits, and withdrawals. Kenyan researchers selected one youth with a high savings balance and one with a low savings balance. The research team in Ghana selected youth who had made a sufficient number of transactions to be able to speak about the project. Research partners in both countries identified a group of six from which they selected two youths for the case studies. The case studies included additional interviews with the two youths' parents or caregivers and school stakeholders. 
After selecting several youth who met the criteria, the research partners contacted the youth and their parents or caregivers to assess interest and suitability for an interview. Youth had already agreed to participate in the larger research study, which included data collection on their savings balances and transactions; those of age majority (18 years in both Ghana and Kenya) gave consent and those of age minority gave assent after their parents consented. Selected participants signed additional written consent or assent forms to enroll in the interview portion of the study.

\section{Participant Profiles}

In both Ghana and Kenya, research partners selected a male and female youth for in-depth interviews. Kofi ${ }^{2}$ is a 12 -yearold male from Kasoa, Ghana's central region. Kofi's father and the head of Kofi's school participated in in-depth interviews to inform his case study. Kofi attends the sixth level of primary school, has six people in his household, and his father has a salaried job in the private sector. Kofi's future goal is to work as a banker or an engineer.

Abena, a 15-year-old female, shared her story in Accra, the capital city of Ghana, where she attends the first level of junior high school. Abena's mother and a teacher from her school also shared information about Abena's participation in the YouthSave Project. Abena's father works a salaried position to support more than seven people who live in the household. When she grows up, Abena would like to be a bank manager.

Gatete is an 18-year-old male from the market town of Naivasha, Kenya. Gatete lives with his cousins who act as his guardians because his parents are very poor and live far away. His uncle pays his school fees. Gatete's cousin participated in an in-depth interview to discuss YouthSave; she and her husband are self-employed and do some small-scale farming to support their household of six people. The principal of Gatete's school also shared his observations of the YouthSave Project and how the project worked for Gatete and more than 500 students in the school. Gatete is in the fourth level of high school and hopes to attend university after completing his secondary education.

Akilah is a 16-year-old female student in the third level of an all-girl secondary school in Migori town in southern Kenya. A teacher at her school shared about Akilah's participation in the YouthSave Project during his interview and related his own experience with Postbank dating back to his university days. Akilah's mother is a single parent who provides for a household of five people with income from a casual job and small farming activities. Akilah would like to open her own business in the future.

\footnotetext{
${ }^{2}$ All names in this manuscript are pseudonyms to protect privacy.
}

\section{Data Collection Procedures}

To ensure standardized data collection methodology across each country, all YouthSave research partners participated in a 1-day workshop on selection of youth, data collection procedures, and in-depth interviewing techniques (April 2012). In-country research partners scheduled the interviews, and trained members of the research team conducted them. Members of the research team conducted interviews alone or in pairs. Research partners scheduled interviews at the location most convenient for the respondent and where he or she felt comfortable speaking freely (e.g., home, school, place of work). Research partners conducted all interviews in the local language, and interviews did not exceed $90 \mathrm{~min}$. Per incountry standards for research, the research team offered at their discretion financial or in-kind incentives to the participants. Examples included a meal, a pen or notebook, or a small contribution to the youth's savings account.

\section{Data Analysis}

The research partners audiotaped the interviews and transcribed them in English. Both local research partners and members of the CSD research team analyzed the data. To help classify the data into themes, the research team first coded the transcripts according to a priori codes and then added additional codes that reflected the context of this project. The research team aggregated findings from Ghana and Kenya to look for meanings related to savings and used cross-case synthesis to identify similarities and differences across cases to develop "naturalistic generalizations" that might be applied to youth saving (Creswell 2013). Research partners also provided data on in-country context from observation, document review, media review, and visual materials, such as photographs. The research team discussed the themes and findings with the in-country research partners to reach consensus and confirm that the themes and constructs identified were consistent with the in-country interpretations.

\section{Results}

\section{Facilitators for Youth Saving}

In the process of participating in the YouthSave Project, youth, parents, and stakeholders identified three core sets of positive facilitators in youth saving. Respondents most frequently mentioned support from parents, followed by support from the school, which includes financial education, support from administrators and teachers, and extracurricular activities. The third facilitator of youth saving that youth, parents, and stakeholders identified is support from the financial institution. 


\section{Support from Parents}

In interviews with youth, parents, and stakeholders, every respondent mentioned the importance of parental and family support. Parental and family support took several forms in the lives of respondents. Youth said that their parents' example of participating in saving could motivate youth themselves to save. For example, 16-year-old Akilah from Kenya recalled, "When my mom opened the account, so I heard saving, saving, saving. So, I also wanted to save...."

Youth, parents, and stakeholders all mentioned the importance of parents playing a practical or logistical role in supporting savings behavior. Eleven-year-old Kofi from Ghana said that he keeps all of his deposit stubs in his father's bedroom out of security concerns. His established saving mechanism involved keeping his weekly savings in his father's bedroom drawer before depositing it at Postbank every Friday. Other youth relayed stories of their parents taking them to the bank for deposits.

Parental encouragement was also important to youth. Kofi's father in Ghana was very pleased to learn that his son had an opportunity to save. Like other parents, he encouraged saving by reminding Kofi about the importance of saving:

When he [my son] told me I was very happy. I was very excited that this bank HFC is doing Enidaso savings accounts for the young ones. They have a good plan for the children of the nation or the children of the world... Really I always advise him that the money he gets he should not spend it roughly because you do not know what is going to happen in the future. I think he takes that advice - even in the house whatever money he gets, he makes sure that he puts some of it in the box... What I always tell him is that the money he gets he should not consume it all. He should keep some aside, because he may need something I don't have the money to give him, and then he can use that money to buy it.

In almost every case, parents and other family members were the main source of income for the youth to deposit into the YouthSave account. In some cases, this was money given to the youth for making a deposit; in other cases, it was money for food or transport that the youth chose to save instead of spend. Eighteen-year-old Gatete of Kenya shared how he saved bus fare to make deposits:

When I come home, you know, is very far, so I am given a fare of maybe one month. So, sometimes we find a lift home because those vehicle of [the agricultural research institute], they carry us. So, I save that money...I just save a little, even if it's $20 \ldots 20$ bob a day, I just save it and then I collect it. When it reaches like a hundred, then

I go and deposit the money to the bank.

\section{Support from the School}

Youth, parent, and stakeholder interviews provided details of specific ways that saving was made easier for youth because of programs or staff at the youth's school. Several youth and stakeholders referenced financial education provided by schools as a way in which they learned more about saving. Financial education also helped youth become more familiar and comfortable with banking in a financial institution. Youth and parents or caregivers identified teachers and school administrators as essential supporters of the YouthSave program and as individuals who helped make saving possible for a number of students. School stakeholders also said that peers and extracurricular activities helped motivate students to save.

Financial Education Schools in both Ghana and Kenya offer financial-education courses. Through the school financialeducation curriculum, youth respondents gain a basic understanding of savings and are taught reasons for saving. Gatete from Kenya reported that during a lesson in business studies at school, he learned about "money and banking" as well as savings and "the types of accounts." Fifteen-year-old Abena from Ghana believed that her education at school reinforced what she was learning at home from family members: "I learned that if you are saving, it helps you to provide for your needs and also helps your mother to further your education for you." Kofi's teacher explained that the school both taught financial education during social studies coursework and also reinforced the knowledge via presentations from financial institutions and discussions at school assemblies:

...Some organizations come here and we always give them the opportunity to address the children... They come to tell them about the products that are suitable for them as a student... Sometimes, at the assembly twice a week we talk on general topics... Maybe one day we discuss savings... The teacher on duty elaborates on the topic and the children participate actively.

Gatete's principal in Kenya shared how his school provides financial education in line with the Kenyan governmental requirement and how students with particular interest in the subject may continue receiving financial education for several years:

[T] eaching of finances is taught as a subject right from Form One...It's a requirement that they study Business Education... The finances are taught there...It's compulsory. So, those who wish to go specific - to continue 
with it - from Form Three to Form Four they choose... Business is an optional subject.

Support from School Stakeholders Both HFC of Ghana and the Postbank of Kenya work directly with schools to raise awareness of the YouthSave account, and the support from school stakeholders is a crucial part of the youth's engagement in the project. School stakeholders mobilize students to connect them to bank staff, relay information from the bank to the students' parents, and help collect and consolidate deposits from the students for the bank staff's easy collection. The indepth interviews frequently revealed the importance of the role that teachers and the school stakeholders play. For example, a teacher from Abena's school in Ghana who helped a parent open a savings account for her child said,

Once a parent came to me, I didn't know her but apparently her child explained the YouthSave account to her and she came here to me to find out the requirements because the girl could not give the details. So she came to ask me what she needed to open the account, and she went back and brought it, so I took her to the bank, and then she opened the account for her child.

Extracurricular Activities and Peer Support Several youth and teachers mentioned the positive and motivating influence of clubs, peers, and competitions at school to encourage saving. The principal of Gatete's school noted that students in the school had begun competing to see who could attain the highest savings balance. He was impressed that one of the best savers was one of the poorest children in the school. The head of Kofi's school in Ghana also discussed the role of peers and identified Kofi as a role model who positively influences the students around him to save:

[E]very week he finds time to take the money personally there [to the bank], and it's surprising when he is going-you find a lot of children following him, as if Kofi has now become a hero...I think most of the children who have subscribed to this account are from Kofi's class. So I think that Kofi has had a great impact even on his mates.

Akilah's teacher in Kenya discussed the role of clubs in his interview:

[S]ome [students] went ahead through a club known as Junior Achievers and opened accounts... at Junior Achievers when they go for these kinds of retreat... they normally are taught about the savings and how they can improve...
He also mentioned that some students in the YouthSave program were motivated by an incentive program that rewarded the highest savers with a small additional deposit into their account, while others were motivated to save regardless of incentives:

[W] hen they learned of the competition and what they could earn from that...some had that opinion that at the end of the competition, they will add some coins into whatever they have... but [for] others...you will see that their main interest is not on the extra shilling that [they] will get, but their main interest is to have an account.

\section{Support from Financial Institutions}

The stories that respondents shared reflected the important role that financial institutions play in facilitating youth saving. The most important elements of support from financial institutions according to YouthSave participants are the bank's staff, good procedures, and the reputation of the institutions. Youth and school administrators articulated the supportive role that bank staff have played in facilitating youth saving at school and bank branches, and youth noted that they appreciated the friendly and easy account-opening procedures. Youth, parents, and teachers expressed their trust in the YouthSave financial institutions, which was conducive to youth saving.

Bank Staff Support Bank staff have been key facilitators in both opening accounts and helping youth make deposits into them. They visit schools and introduce the savings accounts to youth. In certain schools in Ghana, bank staff have arranged to pick up deposits from youth at school at specified times. In general, bank staff are supportive of youth participants in their saving experience in the YouthSave Project. Kofi from Ghana reported,

Once I wanted to go and deposit money into my account. When I got to the market I saw one of the bank men who came to our school to open the account for us. I told him that I wanted to go and deposit so he sent me to the bank and he gave me my account number and he showed me how to deposit the money. School administrators also expressed appreciation for the way the bank staff come to the school and facilitate student savings. The head of Kofi's school noted,

Twice in a term [the bank staff] pick up monies deposited with the headmaster... how they are doing it is very good...they come promptly. For example, this morning 
I called them. I said, "Come, we have some money," and they responded by coming the same day.

Youth-Friendly Procedures Given that HFC and Postbank have made the account-opening process youth-friendly, youth reported that their experience in opening savings accounts were streamlined and easy. It involves simple tasks, such as checking parental identification, filling out some forms, and signing names on the form. Akilah from Kenya recalled her first experience opening the SMATA account:

When I went there [to the bank], we were asked to give out the ID number of [our parents]. Then as we gave them, they took photos of us, then they gave us some forms to answer the questions. As we answered them, we went to the cashier, and we were given the smart cards...then the accounts were there... Gatete from Kenya described his simple and fast experience with opening an account: "The agents gave us some papers that we filled in with our details, and then we handed those papers over... and then they opened the accounts for us. That's how we opened the accounts."

Abena from Ghana confirmed that the bank staff taught students how to fill out the application form, so when she came to the bank, opening an account was a straightforward procedure: "When I came, I took the pen and I wrote my name and my mother's name and I wrote my account number, the date and I signed."

Customers' Trust and Confidence In-depth interviews reflected the trust that youth, parents, and school stakeholders have in the institutions. Customers consider banks in both countries to be trustworthy and safe places to deposit money, which contributed positively to youth saving. Kofi's father said,

I know that HFC they are a very good bank. They can't go to schools and tell the school authorities that they wanted to deal with the young ones when they know that pupils or students don't have money or they are not working. So I know that they can't deceive them. They will make sure that they keep the money very safe. Abena's teacher in Ghana had enough confidence in the bank to set an example by not only owning a personal account there but also recommending it to others:

Yes, I'm an account holder at HFC. I maintain a current account with them and I was so impressed with their customer relations that I recommended the bank to my church... I go there regularly and I'm happy with the way you are received and the way the whole transaction goes on. And when the officials also come to talk with parents of the school children, I like the way they conduct their business...

\section{Obstacles to Saving}

Youth, parents, and stakeholders identified personal and situational obstacles that youth encountered to saving. Lack of financial resources is a major hurdle and creates difficulty in the daily lives of young savers and their families. Juggling conflicting demands on youth income also challenges youth to allocate limited income. School administrators reported that a lack of encouragement or guidance from adults causes some youth to miss the opportunity to save.

\section{Lack of Financial Resources}

A lack of financial resources was the most frequently mentioned obstacle that youth respondents face in Ghana and Kenya. All of the youth are currently in school and not working, so their source of income is unstable and they must rely on others for money for their deposits.

Three of the four youth profiled in the case studies come from families where financial resources are very tight. Abena from Ghana shared this in her story:

Sometimes if I am coming [to the bank], my mother will say that [she does not] have money to give to me to deposit. And also my mother gives me only two cedi [ US\$ 0.60] a day. So I can't come [to the bank] like other people.

Gatete from Kenya lives with relatives who manage to pay his school fees but have little extra to give him for saving. He struggles to find funds to deposit:

I have not made any deposits because my family is facing some financial problems, so that the money they used to give me for 1 month they are not giving me now, and then the money I was getting to buy the snacks they don't usually give me now. So I have no alternative of getting the money because I am always in school.

His family background is similar to his fellow schoolmates, according to the school principal, who expressed admiration that many of them do still manage to save:

Well, I think that the students that we have... they come from a clientele that we can call the "urban poor." They have issue with school fees, their access to money is 
quite limited. But I am happy that when you talk to them the little money that they are accessing they are able to - after getting their basic needs - they are able to start saving...

\section{Conflicting Demands on Youth Income}

Another frequent barrier to saving mentioned in participants' stories is conflicting demands for the use of money. Youth reported that there are many expenses (e.g., school supplies, clothes, shoes, snacks) that conflict with their savings behavior. Abena discussed her expenses and desire to save. She illustrated the decision-making process for a scenario if she received two cedis from her parents: "I spend one cedi [US\$ 0.31 ] for my food. It will leave me with one cedi. I will pay for my studies 60 pesewas [US\$ 0.19], so it will leave me with 40 pesewas [US\$ 0.12] [remaining to save]."

Gatete described how he overcomes the temptations from unnecessary spending:

In order to save, you have to deny yourself... some luxuries, so I usually denied myself... instead of going and eating or enjoying... maybe like buying something, I usually go and save this money so that it can help me in future.

Similarly, Kofi was proud that he stopped purchasing yogurt for a while so he could save toward important things. His father expressed minor concerns about the potential conflicting demands on savings for his son: "That is why I am saying, really any money he gets he should make sure that he doesn't use it to buy toffee and the rest. He should make sure that he uses the money wisely."

\section{Lack of Encouragement or Guidance}

As they considered and compared the different savings behavior of multiple youth in their educational institutions or communities, school stakeholders identified one common barrier in their stories. They noted that the youth selected for the indepth interviews were good role models for saving, but they emphasized that other youth unnecessarily disqualified themselves from saving because they believe it requires large amounts of money. Alternatively, some youth had money to save but lacked encouragement or support, according to Gatete's principal in Kenya:

I think they didn't have a formula, they didn't have a focus, they didn't have somebody, they didn't have a guiding factor, they were just being given money... I was asking them..."do you have another system of saving?" They were telling me, no. It's only that they had not gotten someone to guide them and tell them money can be saved. They were only living [as] spenders; they didn't know that one can save even if you're saving only a little money.

\section{Discussion}

In-depth interviews illuminate savings experiences of youth in the YouthSave Project and highlight factors that make saving easy or difficult for them. Stories shared by parents and school-based stakeholders complement the youth interviews and add the broader context in which the youth are saving.

Findings are mostly consistent with institutional theory on saving (Beverly et al. 2008). The behaviors of individuals are important, but institutional features play an important role in facilitating or hindering saving. Youth in two Sub-Saharan African countries struggle with limited resources, conflicting demands on funds, and lack of guidance, yet the youth profiled continue to save. These youth report that the people around them - parents, family members, school stakeholders, peers, and bank staff-play a major role in opening accounts and making deposits. Family members, especially parents, had either provided an example of saving for them to follow or had more directly assisted them.

Youth and supportive adults also acknowledge efforts of financial institutions to facilitate savings behavior. Foremost, the availability of the YouthSave account makes formal saving possible. Institutions can build on demand created by the aspirations of youth and their families and their desire to create better futures for themselves; institutions encourage savings by providing access, information, and a trustworthy place for deposits (Beverly et al. 2008). The study demonstrates strategies through which financial institutions and schools in Ghana and Kenya have influenced youth saving. Youth do save when it is easy to open an account and make deposits and when the financial institution is considered trustworthy. Both financial partners, HFC of Ghana and Postbank of Kenya, provided access to saving for youth at schools, where most schoolgoing youth spend a significant amount of time during the day. Both banks in the project made use of media, school venues, and markets to disseminate the information of savings accounts they offer. Both banks also deployed sales agents and staff to promote the saving accounts and facilitate youth at various locations to save. Student reports of training they received and its impact on their behaviors aligned with stakeholder reports regarding curriculum, and reinforce findings from other research on the importance of institutional factors and financial education for promoting savings (Sherraden et al. 2013).

Study findings on obstacles to youth saving are consistent not only with reports of the challenging financial 
circumstances many youth face in Sub-Saharan Africa, but also with prior qualitative work in the United States in which youth identified limited employment and competition for funds as barriers to saving (Wheeler-Brooks and Scanlon 2009). Findings also confirmed prior research noting that a lack of guidance on saving or financial management can be a hindrance to youth saving (International Labour Organisation 2012; Sherraden et al. 2013; Wheeler-Brooks and Scanlon 2009). This may indicate yet another opportunity for financial institutions to encourage saving by providing facilitation via personnel or information.

This study contributes to the limited research on the lived experiences of youth in Ghana and Kenya while saving. As noted, the majority of in-depth studies of youth and saving come from the USA. Interviews with Ghanaian and Kenyan youth provide valuable information for modifying or developing savings policies, products, and programs that target youth. Policymakers and practitioners should consider the influence of both individual and institutional factors that promote savings and respond accordingly. Results from this study suggest that parents and youth who are motivated to save but constrained by limited resources may benefit from reduced educational costs and additional income generation opportunities. Policies can encourage or incentivize additional educational institutions to provide financial education and promote access to financial institutions. Feedback from youth in this study indicates that programs to train school stakeholders may be an important way to reach youth and encourage saving. Financial institutions have the potential to improve youth's access to banking by promoting products attractive to youth, making procedures simple, and engaging parents or caregivers and school stakeholders.

Though informative, the study does have limitations. Case studies with a small sample are not generalizable, even to youth within the YouthSave program. Case study participants were selected purposively based on savings behavior, and their stories are not representative of other participants. Additionally, the study relies on self-reports from very young participants who may have responded with socially desirable responses to an interviewer in a position of perceived authority.

\section{Conclusions}

As the youth population in Sub-Saharan Africa continues to grow, the need for its financial inclusion becomes more important. The stories of Ghanaian and Kenyan youth who are actively participating in saving can provide information for policymakers and financial institutions seeking to promote youth-focused savings products. Programs to promote savings should build on the active support network around youth, including parents, school personnel, and peers. Financial education in schools or from financial institutions is important to build confidence and encourage savings. Financial institutions that make it easy for youth to open accounts and make deposits are more likely to build youth savings.

Acknowledgments The authors would like to express their gratitude to Dr. Michael Sherraden for his leadership as the principal investigator of the YouthSave research; to Drs. Gina Chowa and Fred Ssewamala for their leadership as the co-investigators of the YouthSave research in Ghana and Kenya, respectively; to the YouthSave Consortium partners for their collaboration on the YouthSave Project and constructive suggestions to improve this manuscript; to the MasterCard Foundation for generous support to the YouthSave Project; and to John Gabbert for the skillful editing of this work.

This manuscript is a product of the YouthSave Project. Created in partnership with the MasterCard Foundation, YouthSave investigates the potential of savings accounts as a tool for youth development and financial inclusion in developing countries by co-designing tailored, sustainable savings products with local financial institutions and assessing their performance and development outcomes with local researchers. The project is an initiative of the YouthSave Consortium, led by Save the Children in partnership with the Center for Social Development at Washington University in St. Louis, the New America Foundation, and CGAP.

\section{References}

Beverly, S., Sherraden, M., Zhan, M., Williams Shanks, T. R., Nam, Y., \& Cramer, R. (2008). Determinants of asset building (Urban Institute Poor Finances Series). Washington: The Urban Institute.

Center for Social Development. (2011). Broad and deep: the extensive learning agenda in YouthSave. St. Louis: Washington University, Center for Social Development.

Center for Strategic and International Studies and International Youth Foundation. (2014). The global youth well-being index. Retrieved from http://www.youthindex.org/reports/globalyouthwellbeingindex. pdf.

Child and Youth Finance International Research Working Group. (2012). Children and youth as economic citizens: review of research on financial capability, financial inclusion, and financial education. Amsterdam: Research Working Group Report, Child and Youth Financial International.

Child and Youth Finance International Research Working Group. (2013). Children youth and finance: from momentum to action. Amsterdam: Child and Youth Financial International. Retrieved from http:// childfinanceinternational.org/resources/publications/childrenyouth-finance-from-momentum-to-action.pdf.

Chowa, G., Masa, R., Wretman, C., \& Ansong, D. (2013). The impact of household possessions on youth's academic achievement in the Ghana YouthSave experiment: a propensity score analysis. Economics of Education Review, 33, 69-81. doi:10.1016/j. econedurev.2012.08.005.

Creswell, J. W. (2013). Qualitative inquiry and research design: choosing among five approaches. Thousand Oaks: Sage publications.

Demirguc-Kunt, A., \& Klapper, L. (2012). Measuring financial inclusion: the Global Findex Database. World Bank eAtlas of Financial Inclusion. Retrieved from http://www.app. collinsindicate.com/worldbankatlas-fi/en-us.

Deshpande, R. (2012). What do youth savers want? Results from market research in four countries (Save the Children YouthSave Note). Washington: Save the Children.

Hervish, A., \& Clifton, D. (2012). Status report on adolescents and young people in Sub-Saharan Africa: opportunities and challenges. United 
Nations Population Fund and Population Reference Bureau. Retrieved from http://www.prb.org/Publications/Reports.aspx.

Huang, J., Sherraden, M., Kim, Y., \& Clancy, M. (2014). Effects of child development accounts on early social-emotional development: an experimental test. JAMA Pediatrics, 168(3), 265-271. doi:10. 1001/jamapediatrics.2013.4643.

International Labour Organisation. (2012). Global employment trends 2012. International Labour Organisation. Retrieved from http:// ilo.org/global/research/global-reports/global-employment-trends/ 2012/lang-en/index.htm.

Ismayilova, L., Ssewamala, F., Mooers, E., Nabunya, P., \& Sheshadri, S. (2012). Imagining the future: community perceptions of a familybased economic empowerment intervention for AIDS-orphaned adolescents in Uganda. Children and Youth Services Review, 34(10), 2042-2051.

Kilara, T., Magnoni, B., \& Zimmerman, E. (2014). The business case for youth savings: a framework. CGAP. Retrieved from http://www. cgap.org/publications/business-case-youth-savings-framework.

Montez, D. (2010). Young Africans' access to financial information and services: lessons from surveys in Kenya and Ghana. AudienceScapes: Development Research Briefs. Retrieved from http:/www.audiencescapes.org/sites/default/files/Youth\%20and $\%$ 20Financial $\% 20$ Services_Kenya $\% 20$ and $\% 20$ Ghana_Montez $\%$ 20David.pdf.

Murphy-Erby, Y., Hamilton, L., Shobe, M., Christy, K., Hampton-Stover, E., \& Jordan, S. (2014). Preparing children for success: parents' perspectives on promoting savings and education. Journal of Family Issues, 35(9), 1177-1199.

Scanlon, E., \& Adams, D. (2008). Do assets affect well-being? Perceptions of youth in a matched savings program. Journal of Social Service Research, 35(1), 33-46.

Scanlon, E., Buford, A., \& Dawn, K. (2009). Matched savings accounts: a study of youths' perceptions of program and account design. Children and Youth Services Review, 31(6), 680-687.
Sharma, S., Zou, L., Johnson, E., Lee, Y., \& Lama, G. (2015). Savings accounts for youth: Initial findings from Nepal. In M. Sherraden, L. Zou, S. Deng, H. Ku, \& S. Wang (Eds.), Asset-building policies and innovations in Asia (pp. 152-169). Oxford: Routledge.

Sherraden, M., McBride, A. M., Johnson, E., Hanson, S., Ssewamala, F., \& Shanks, T. (2005). Saving in low-income households: evidence from interviews with participants in the American Dream Demonstration. (CSD Report 05-02). St. Louis: Washington University, Center for Social Development.

Sherraden, M., Peters, C., Wagner, K., Guo, B., \& Clancy, M. (2013). Contributions of qualitative research to understanding savings for children and youth. Economics of Education Review, 32, 66-77.

Ssewamala, F. M., Han, C. K., \& Neilands, T. B. (2009). Asset ownership and health and mental health functioning among AIDS-orphaned adolescents: findings from a randomized clinical trial in rural Uganda. Social Science \& Medicine, 69(2), 191-198. doi:10.1016/ j.socscimed.2009.05.019.

Ssewamala, F. M., Sperber, E., Blake, C. A., \& Ilic, V. P. (2012). Increasing opportunities for inner-city youth: the feasibility of an economic empowerment model in East Harlem and the South Bronx, New York. Children and Youth Services Review, 34(1), 218-224.

UNICEF. (2014). Generation 2030/AFRICA. United Nations Children's Fund. Retrieved from http://www.unicef.org/publications/index 74751.html.

Wheeler-Brooks, J., \& Scanlon, E. (2009). Perceived facilitators and barriers to saving among low-income youth. The Journal of SocioEconomics, 38(5), 757-763.

World Bank. (2014). Global financial development report 2014: financial inclusion. Washington: World Bank. doi:10.1596/978-0-82139985-9.

Zou, L., \& Sherraden, M. (2009). From “dead" savings to assets for life: perspectives on the retirement social insurance pilot project in Hutubi, China. Asia Pacific Journal of Social Work and Development, 19(1), 96-115. 